\title{
Developing designs in balance with nature
}

\author{
A. J. Anselm \\ School of Architecture and Urban Planning, \\ Huazhong University of Science and Technology, \\ Wuhan, People's Republic of China
}

\begin{abstract}
Recent developments especially in the areas of ecology and architecture have identified an unhealthy relationship between the built environment and nature. The breakthroughs in science and technology through the late 18th century saw an explosion in the trends/types of architectures that are presently characterized by their polluted, machine-dominated, dehumanizing, and environmentally unfriendly natures. This trend which in collaboration with other environmental defiant practices also contribute in the fast depleting, explosion-threatened world that is even now disintegrating and disappearing before our eyes. Time is quickly running out for our society to rethink the way we plan for development of the remaining open spaces.

The main objective here is to confer ideas aimed at creating environmentally friendly, energy-efficient buildings developed by effectively managing natural resources. This entails passively and actively harnessing solar energy and using materials which, in their manufacture, application, and disposal, do the least possible damage to nature's 'free resources'; water, ground, and air. This involves identifying factors that affect a healthy natural environment such as choice of building site, orientation, choice of building materials (in other words, let where it is be where it is made of) and methods of combining these building materials in order to achieve balance.

Keywords: designing with nature, eco-architecture, ecological designs, building with nature, sustainable designs, resource efficient design, energy efficient designs, harmonization with nature, design.
\end{abstract}




\section{Introduction}

A pure natural environment is the epitome of health and vice versa, a condition that is the primary desire of all that exists within it. The earth is an emotional entity and nature, the result of its emotions. Man made and natural disasters are the means of expression of sadness or pain that the earth feels, thus when the earth hurts, nature cries, likewise when the earth is in health, nature smiles.

Man's activities through time produce adverse effects to the health of the earth and its expression through nature, and since we are all property of the earth and not left out when nature cries, it is then mandatory for man to learn means of appeasing the earth by means of harmonizing his activities with earth's most cherished progeny... nature.

The quest for an ecological understanding and approach in all of man's endeavours and activities, has become a challenge to all that care about nature as it is obviously a systematic method of restoration back to nature, hence a more healthy earth. It is a call that should be answered totally by all professional disciplines, as one un-ecological activity can prove retrogressive to the efforts of so many. Since architecture contribute in making the built environment, ecology should then be employed as one of its vital tools or element of architectural designs. Our design and construction trend, has witnessed changes and transformations from industrialization to machinism, a trend which in recent times is characterized as unfriendly to nature. Designing and building with or in harmony with nature is the one efficient concept which works towards integrating the elements of balance between the built environment and nature.

\section{Understanding the natural environment}

The surface of the Earth as a whole is an Ecosystem, called the Biosphere.

The Biosphere or the surface of the Earth constitutes nature's 'free resources' air, water, and land, where living things exist.

The Biosphere with a structure of smaller units called Ecosystems includes all the Organisms and the Nonliving Environment found in a particular place, and this also includes our built environment, an area that needs to be integrated into the ecosystem without negatively affecting the balance in the ecosystem itself.

Understanding the natural environment is the first step towards achieving a nature integral design. It entails understanding nature's environmental activities, the Ecosystem and its actions and reactions that will relate to building designs. The constant use of such analytical processes that determine and define functions of building designs and its corresponding effect to the immediate and distant environment should not be neglected. These procedures like the environmental conservation, environmental impact assessment, integrated assessment etc, which are normally undertaken for individual projects such as dams, motorways, airports or factories should be broadened to include damage assessment, ecological replacement systems or ecology integration solution for smaller project designs like commercial and residential buildings. 


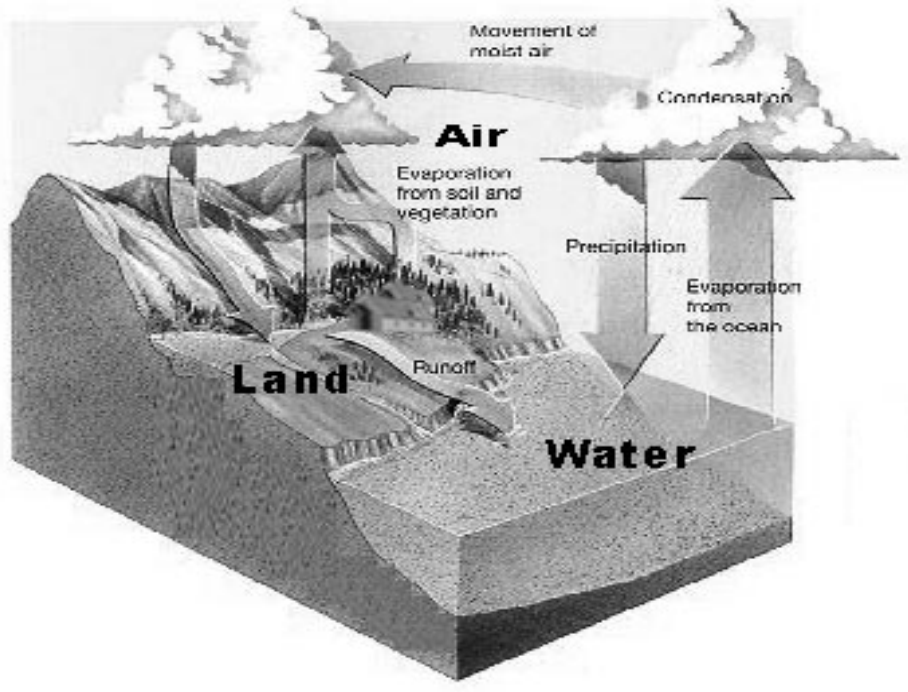

Figure 1: The ecosystem structure.

\subsection{Traditional approach; ecology integration solution}

An argument once arose that the one way to protect the environment is for society to place a monetary value on it, and then sue any firm or individual that damages it. But how can society measure the economic damage caused by environmental injury? The ecological replacement solution is an idea that discusses ecological solutions in a small or larger scale for the restoration of damages or injury caused by tampering with the natural (green) environment in the intent of building development. This idea has been utilized in the past based on local knowledge or unconscious attempts to balance the immediate natural environment around the built environment. Such local knowledge, usually acquired through experience and oral transmission, often accounts for the interrelationships among animals, plants, humans and the environment, resembling in some aspects ecological concepts held by scientists (Berkes et al., [3]). Thus, local ecological knowledge is an important keystone to the design and structure of natural resource management strategies. In nature there is no waste, the byproduct of one organism becomes the food for another. In other words, natural systems are made of closed loops. By working with living processes, we respect the needs of all species. Engaging processes that regenerate rather than deplete, we become more alive. Making natural cycles and processes visibly brings the designed environment back to life

Building designs and construction take up natural foliage spaces or natural landforms. These natural landforms or foliage that supports some useful ecological organisms should be replaced systematically in order to ensure resuscitation of displaced plants and organisms which are also necessary for an ecological balance. The percentage of replacement may depend on the function 
of the structure or architecture and also on the construction techniques employed as shown in figure 2 below. Such replacements, enhances the energy efficiency and overall thermal and environmental comfort of the area involved.

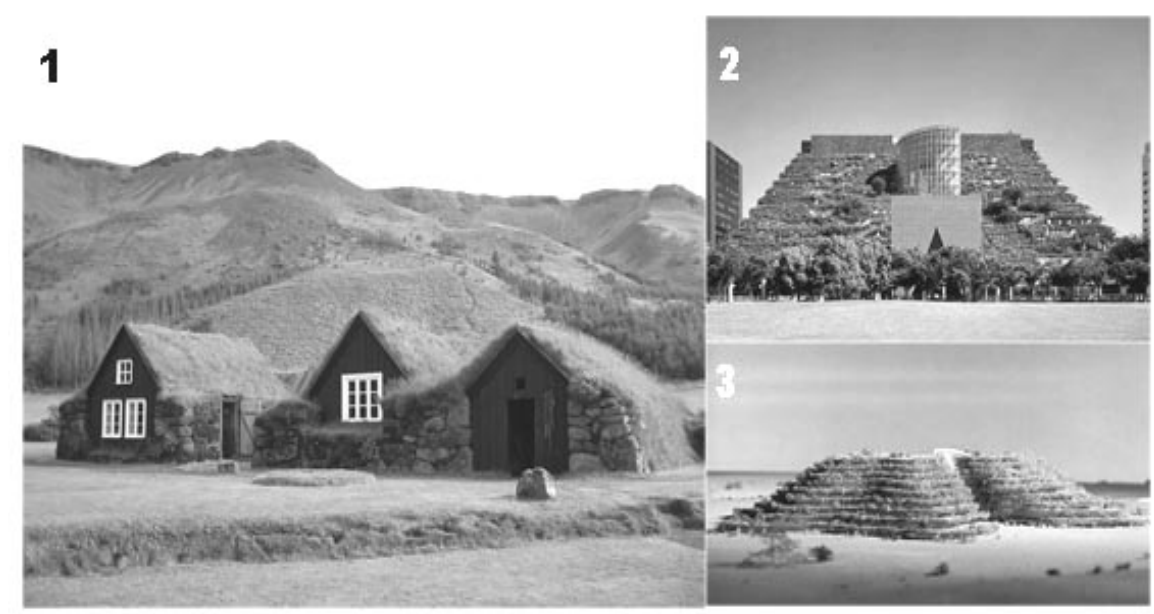

Figure 2: Example of the traditional concept on ecological replacement as seen in the traditional Turf (grass covered) houses in Iceland (1), and the modern approach as expressed in the designs of architect Emilio Ambasz (2) and (3).

\section{Managing the natural environment and resources}

Designing with nature entails managing the three basic nature-resources of air, land and water. This also involves utilizing design elements and ideas that will make best use of these nature-resources and their extended influences that may be human friendly or otherwise. Careful consideration is needed in the choice of topography and terrain, and the management of climate and energy.

\subsection{Orientation and choice of building site}

A building site is the closest environment to any proposed building plan; it forms the immediate atmosphere for the occupants of such a building and it is expected to satisfy the desires of the proposed occupants as well as satisfying the environment that will host it. Designing with nature begins with an intimate understanding of place. With active sensitivity to the nuances of place, we can inhabit without destroying it, be it a plain, undulating or steeply terrain, the landform is to be carried along in the design concept. A careful design plan and construction technique will see to less damage to the topographical structure of the building site. Understanding place helps determine design practices such as solar orientation of a building on the site, designing with existing topography pattern and finally the preservation of the natural environment, whether the 
design site is a building in the inner city or in a more natural setting, connecting with nature brings the designed environment back to life. Effective design helps inform us of our place within nature.

Regional climatic conditions or local climate which define the choices of building orientation when rightly managed and effectively considered in building design and orientation forms a source of energy conservation and management. Advanced climatic research identifies that most tropical building designs gain more in energy conservation by the use of the south/north or north-east/southwest orientation as against the east/west orientation for purposes of better wind flow, ventilation and sun shading, likewise temperate designs with the south/north alternative for the major purposes of winter heat gains. A survey indicates that most residential buildings with an elongated east-west orientation, built virtually anywhere in the United States, will experience a $10 \%$ reduction in energy consumption compared to a square building, and a $20 \%$ reduction compared to a north-south building. This then indicates that choice of building orientation can make best use of the natural conditions of a place to achieve the desired thermal comfort with or without a combined use of other sustainable energy sources like the solar photovoltaic or the wind energy generators.

\subsection{Climate integrated design}

Climate is an inevitable member of nature and its effects some times are unpredictable. The Sun, land, and water interact in complicated ways throughout each day and throughout the year, and the result is what we commonly refer to as weather. These interactions produce daily as well as seasonal temperature, humidity, and wind patterns that can vary substantially between locations in close geographic proximity. A Climate-integrated design is a strategy that seeks to take advantage of the positive climate attributes of a particular location, while minimizing the effects of attributes that may impair comfort or increase energy requirements. A climate-integrated design should consider the following points.

1. Understand climate zones and microclimates

2. Understand the basic physiology of human thermal comfort

3. Control the sun to reduce loads and enhance visual comfort

4. Use thermal mass to improve comfort and efficiency

5. Utilize the local winds and breezes as much as can be harnessed for improved comfort.

6. Finally, effective choice of material and design technique for optimized results.

The microclimate of a building site can make or break a climate responsive design, for instance to better harness the solar rays for a passive design or a solar energy design, the solar path needs to be evaluated, as shadows cast by nearby buildings, trees, or hills are important considerations in orienting a solar collector or designing a passive solar building. The proper study of the solar path can also effectively provide options of building materials or techniques for better sun shading or solar access. The Figure below shows the behavior of the sun through the seasons and the effects produced which utilized effectively can satisfy the solar requirements in a building design. 

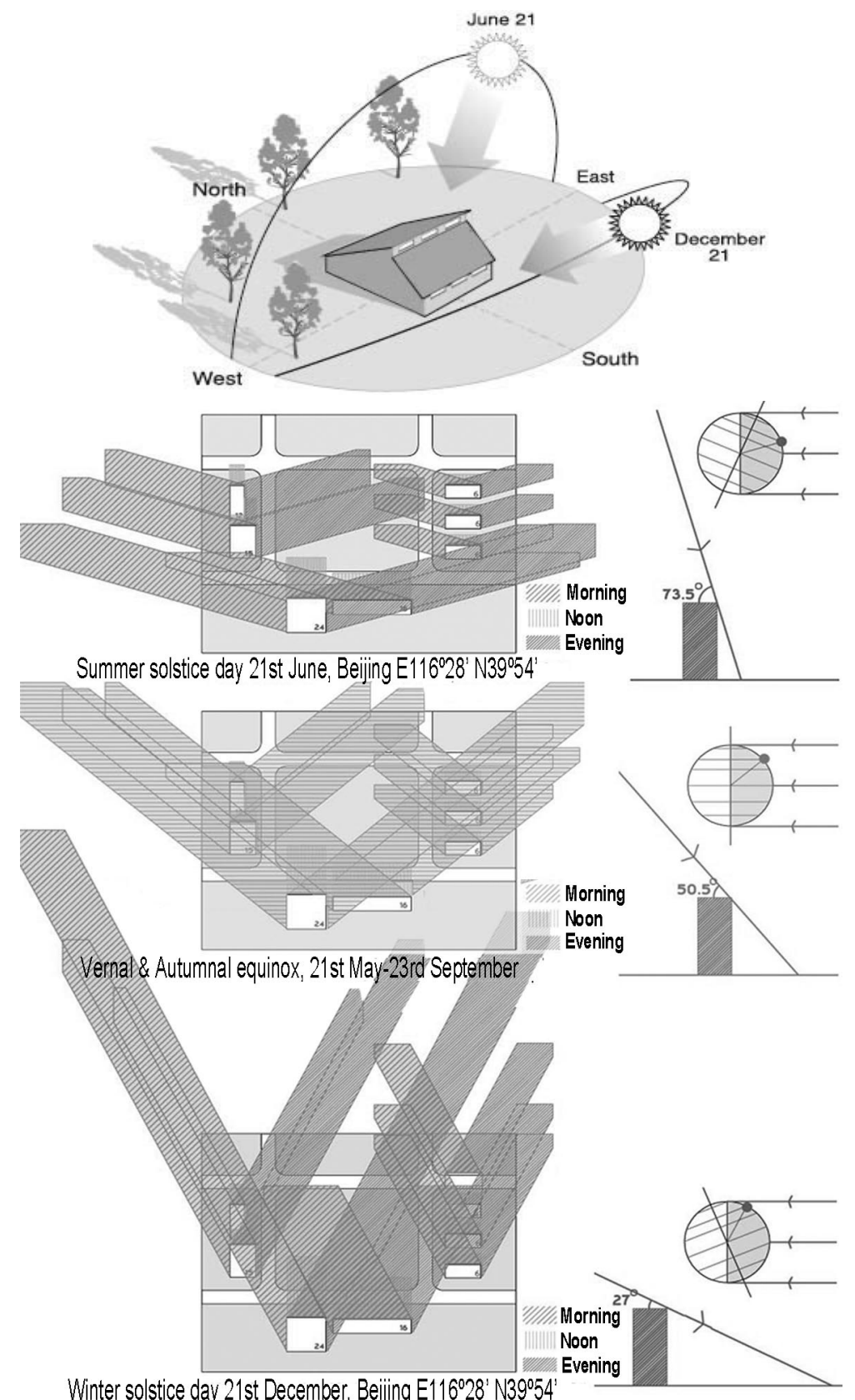

Winter solstice day 21st December, Beijing E116028' N39054'

Figure 3: Showing seasonal solar paths and shadow patterns, the major factors that may affect the orientation of a solar collector and design of a passive solar building. 
Table 1: Design implication for varying climatic conditions.

\begin{tabular}{|c|c|c|}
\hline Climate zone & Characteristics & Design implication \\
\hline $\begin{array}{l}\text { TROPICAL } \\
\text { Hot and humid }\end{array}$ & $\begin{array}{l}\text {-High humidity with a } \\
\text { degree of "dry season". } \\
\text {-High temperatures year } \\
\text { round. } \\
\text {-Minimum seasonal } \\
\text { temperature variation. } \\
\text {-Lowest diurnal (day/night) } \\
\text { temperature range. }\end{array}$ & $\begin{array}{l}\text {-Employ lightweight (low mass) construction. } \\
\text {-Maximize external wall areas (plans with one } \\
\text { room depth are ideal especially for } \\
\text { residential units) to encourage movement of } \\
\text { breezes through the building (i.e. cross } \\
\text { ventilation). } \\
\text {-Shade whole building; consider using fly-roof } \\
\text { and landscaping trees. } \\
\text {-Use reflective insulation and vapor barriers. } \\
\text {-Ventilate roof spaces if possible for optimized } \\
\text { results. } \\
\text {-Consider high or raked ceilings } \\
\text {-Provide screened, shaded outdoor living } \\
\text { areas, also creating sleep-out spaces (for } \\
\text { residential). } \\
\text {-Design and build against windy conditions } \\
\text { and hazards. } \\
\text {-Most essentially, design for a greener } \\
\text { environment. }\end{array}$ \\
\hline $\begin{array}{l}\text { SUB- } \\
\text { TROPICAL } \\
\text { Warm and } \\
\text { humid }\end{array}$ & $\begin{array}{l}\text {-High humidity with a } \\
\text { definite "dry season". } \\
\text {-Hot to very hot summers } \\
\text { with mild winters. } \\
\text {-Distinct summer and winter } \\
\text { seasons. } \\
\text {-Moderate to low diurnal } \\
\text { (day/night) temperature } \\
\text { range. This can vary } \\
\text { significantly between } \\
\text { regions too e.g. inland to } \\
\text { coastal }\end{array}$ & $\begin{array}{l}\text {-Use lightweight construction where diurnal } \\
\text { (day/night) temperature range is low and } \\
\text { include thermal mass where diurnal range is } \\
\text { significant. } \\
\text {-Maximize external wall areas (plans with one } \\
\text { room depth are ideal especially for } \\
\text { residential units) to encourage movement of } \\
\text { breezes through the building (i.e. cross } \\
\text { ventilation). } \\
\text {-Shade whole building where possible in } \\
\text { summer and allow passive solar access in } \\
\text { winter months only. } \\
\text {-Avoid auxiliary air conditioning, good design } \\
\text { techniques does it all. } \\
\text {-Provide screened, shaded outdoor living } \\
\text { areas. } \\
\text {-Most essentially, design for a greener } \\
\text { environment. }\end{array}$ \\
\hline $\begin{array}{l}\text { SUB- } \\
\text { TROPICAL } \\
\text { Hot and } \\
\text { dry/warm } \\
\text { winter }\end{array}$ & $\begin{array}{l}\text {-Distinct wet and dry } \\
\text { seasons. } \\
\text {-Low rainfall and low } \\
\text { humidity. } \\
\text {-No extreme cold but can be } \\
\text { cool in winter. } \\
\text {-Hot to very hot summers. } \\
\text {-Significant diurnal } \\
\text { (day/night) range. }\end{array}$ & $\begin{array}{l}\text {-Use passive solar design and insulated } \\
\text { thermal mass for the external walls. } \\
\text {-Maximize cross ventilation } \\
\text {-Utilize convective (stack) ventilation, which } \\
\text { vents rising hot air while drawing in cooler } \\
\text { air. } \\
\text {-Allow for solar access and exposure to cooling } \\
\text { breezes } \\
\text {-Shade all east and west windows for summer } \\
\text { and build screened, shaded summer outdoor } \\
\text { living areas that allow winter sun } \\
\text { penetration. } \\
\text {-Use trees, garden ponds and water features to } \\
\text { provide evaporative cooling during summers. }\end{array}$ \\
\hline
\end{tabular}


Table 1: $\quad$ Continued.

\begin{tabular}{|c|c|c|}
\hline Climate zone & Characteristics & Design implication \\
\hline $\begin{array}{l}\text { HOT ARID } \\
\text { Hot and dry } \\
\text { cold winter }\end{array}$ & $\begin{array}{l}\text {-Low humidity year round. } \\
\text {-High diurnal (day/night) } \\
\text { temperature range. } \\
\text {-At least two and usually } \\
\text { four distinct seasons with } \\
\text { low rainfall, very hot } \\
\text { summers, cold winters and } \\
\text { hot dry winds in summer. } \\
\text { With cool to cold dry } \\
\text { winds in winter. }\end{array}$ & $\begin{array}{l}\text {-Use passive solar principles with well } \\
\text { insulated thermal mass } \\
\text {-Maximize night time cooling in summer. } \\
\text {-Consider convective (stack) ventilation, which } \\
\text { vents rising hot air and draws in cooler air. } \\
\text {-Build more compact shaped buildings with } \\
\text { good cross ventilation for summer while } \\
\text { maximizing solar access, exposure to cooling } \\
\text { breezes or cool air drainage, and protection } \\
\text { from strong winter (cold) and summer winds. } \\
\text {-Use renewable energy sources for auxiliary } \\
\text { heating in extreme climates } \\
\text {-Use trees, garden ponds and water features to } \\
\text { provide evaporative cooling during summers. }\end{array}$ \\
\hline $\begin{array}{l}\text { TEMPERATE } \\
\text { Warm } \\
\text { temperate }\end{array}$ & $\begin{array}{l}\text {-Low diurnal temperature } \\
\text { range coast to high diurnal } \\
\text { range inland. } \\
\text {-Four distinct seasons. } \\
\text { Summer and winter can } \\
\text { exceed human comfort } \\
\text { range. Spring and autumn } \\
\text { are ideal for human } \\
\text { comfort and mild to cool } \\
\text { winters with low humidity. } \\
\text {-Hot to very hot summers } \\
\text { with moderate humidity. }\end{array}$ & $\begin{array}{l}\text {-Use passive solar principles with well } \\
\text { insulated thermal mass. } \\
\text {-Minimize external wall areas especially east } \\
\text { and west. } \\
\text {-Use cross-ventilation and passive cooling in } \\
\text { summer as well as convective ventilation. } \\
\text {-Allow for solar access, exposure to cooling } \\
\text { breezes and protection from cold winds. } \\
\text {-Seal thoroughly and use entry airlocks } \\
\text {-Avoid auxiliary heating, good design } \\
\text { techniques does it all. } \\
\text {-Use trees, garden ponds and water features to } \\
\text { provide evaporative cooling during summers }\end{array}$ \\
\hline $\begin{array}{l}\text { TEMPERATE } \\
\text { Cool } \\
\text { temperate }\end{array}$ & $\begin{array}{l}\text {-Low humidity. } \\
\text {-High diurnal range. } \\
\text {-Four distinct seasons. } \\
\text { Summer and winter exceed } \\
\text { human comfort range } \\
\text {-Cold to very cold winters } \\
\text { with majority of rainfall. } \\
\text {-Hot dry summers. } \\
\text {-Variable spring and autumn } \\
\text { conditions. }\end{array}$ & $\begin{array}{l}\text {-Use passive solar principles with well } \\
\text { insulated high thermal mass. } \\
\text {-Maximize north facing walls, especially in } \\
\text { living areas with passive solar access. } \\
\text {-Minimize south facing windows. } \\
\text {-Minimize external wall areas especially east } \\
\text { and west. } \\
\text {-Use cross-ventilation and passive cooling in } \\
\text { summer as well as convective ventilation. } \\
\text {-Allow for solar access, exposure to cooling } \\
\text { breezes and protection from cold winds. } \\
\text {-Seal thoroughly and use entry airlocks } \\
\text {-Use renewable energy sources for auxiliary } \\
\text { heating in extreme climates. }\end{array}$ \\
\hline
\end{tabular}

\section{Utilizing nature in building designs}

In the study of nature and design, a vast literature exists. When the two areas are connected, they are mainly referenced under bioclimatic design or vernacular designs with emphasis on basic, good design principles. The Bioclimatic design literature is on the whole more technical and scientific in nature, while Vernacular architecture address issues of culture, tradition and aesthetics as well 
as comfort. These two vital concepts are important in understanding the basic ideas of a nature integrated design.

Table 2: $\quad$ Showing a nature-positive design scheme.

\begin{tabular}{|c|c|c|c|}
\hline $\begin{array}{l}\text { Nature } \\
\text { factor }\end{array}$ & Resource & Building fabric & $\begin{array}{l}\text { Service } \\
\text { implication }\end{array}$ \\
\hline Air & $\begin{array}{l}\text { Free air } \\
\text {-Natural ventilation } \\
\text {-Wind force } \\
\text {-Energy content Stack } \\
\text { effect } \\
\text {-Solar energy, diffuse } \\
\text { radiation } \\
\text {-Solar energy, direct } \\
\text { radiation }\end{array}$ & $\begin{array}{l}\text { Facade and roof } \\
\text {-Light weight or massed } \\
\text { façade. } \\
\text {-Planted surfaces } \\
\text {-Rainwater collectors } \\
\text {-Day light collectors and } \\
\text { Shades } \\
\text {-Passive solar absorber } \\
\text {-Night cooling by outside air. } \\
\text {-Evaporative cooling } \\
\text { Construction } \\
\text {-Courtyards. }\end{array}$ & $\begin{array}{l}\text { Heat energy } \\
\text {-Solar thermal } \\
\text { system } \\
\text {-Wind energy } \\
\text { generator }\end{array}$ \\
\hline Soil & $\begin{array}{l}\text { Groundwater } \\
\text {-Cold energy } \\
\text {-Heat energy } \\
\text { Earth/rock } \\
\text {-Geothermal cooling } \\
\text {-Heat energy } \\
\end{array}$ & $\begin{array}{l}\text { Green zones } \\
\text {-Planted surfaces. } \\
\text { Ground } \\
\text {-Passive solar energy } \\
\text {-Passive cooling energy }\end{array}$ & $\begin{array}{l}\text { Natural } \\
\text { landscaping } \\
\text { services } \\
\text {-Permaculture } \\
\text {-Pools and ponds }\end{array}$ \\
\hline Water & $\begin{array}{l}\text { Lake } \\
\text {-Pump water or } \\
\text { greywater } \\
\text {-Heat/Cold energy } \\
\text { River } \\
\text {-Pump water or } \\
\text { greywater } \\
\text {-Heat/Cold energy } \\
\text { Sea } \\
\text {-Pump water or } \\
\text { greywater } \\
\text {-Heat/Cold energy }\end{array}$ & $\begin{array}{l}\text { Pure water } \\
\text {-Public supply (drinking, } \\
\text { cooking) } \\
\text { Greywater } \\
\text {-Waste water (condenser } \\
\text { water, flushing, cleaning) } \\
\text { Rainwater } \\
\text {-Flushing, cleaning, cooling }\end{array}$ & $\begin{array}{l}\text { Mains supply. } \\
\text { Self supply. } \\
\text {-Bore holes }\end{array}$ \\
\hline
\end{tabular}

\subsection{Resuscitating architecture's endangered species}

Recent studies identify the sustainable properties vernacular architecture and vernacular design principles hold in sustainable building. Although most of the original appearance of vernacular architectures disappeared through the renewals since the ideas of new developments in cities and cultures, there is still a lot of building substance that could be rediscovered as old and historic. There are many wonderful building styles from all over the world that can inform us with their shapes, materials, arrangements, decorations, concepts for heating and cooling, etc. Vernacular architecture has been loosing ground over the last couple of centuries, as modern methods prevail. This is unfortunate since many of the old ways employ natural materials and simple concepts that are energy efficient. Also the buildings themselves are often beautiful and enhance simple live styles which are advantageous to the issue of environmental protection and health. 
As the basic principles that outline a nature-positive design are all innate in the vernacular design concept, vernacular building design ideas should then be encouraged and improved in order to achieve sustainable and healthy nature integrated designs, making use of the local landscape, local materials, orientation, sustainable techniques of recycling and permaculture, local climate and the conscious idea of balance with nature.

\section{Conclusion}

Finally, designs that will be produced using this scheme will be identified as modern vernacular type. Its buildings make best use of sun, wind and rainfall to supply energy and water needs of occupants, be it the tropical or African vernacular type or the temperate vernacular architectures. In the case of multistorey that maximizes the land available for green space, the design should be generally Resource Efficient;

- Energy Efficiency (sustainably harnessed energy).

- Pollution Prevention (including indoor air quality/sustainable material use).

- Harmonization with Environment (including ecological integration, bioclimatic considerations and environmental assessment).

\section{References}

[1] Bailey, K.D., Methods of Social Research. The Free Press, Macmillan Publishers, New York, 1982.

[2] Berkes, F., Sacred Ecology-Traditional Ecological Knowledge and Resource Management. Taylor \& Francis, Philadelphia, 1999.

[3] Berkes, F., Kislalioglu, M., Folke, C., Gadgil, M., Exploring the basic ecological unit: ecosystem-like concepts in traditional societies. Ecosystems, pp. 1, 409-415, 1998.

[4] Gadgil, M., Berkes, F., Folke, C., Indigenous knowledge for biodiversity conservation. Ambio, pp. 22, 151-156, 1993.

[5] E. Cofaign, J. Olley, and J. Lewis, The Climatic Dwelling: An introduction to climate-responsive residential architecture, www.jxj.com, London, 1996.

[6] Koenigsberger, O., Manual of Tropical Housing and Building Design, Longman Group United Kingdom, 1974.

[7] CIBS Guide A2 - Weather and Solar Data, Chartered Institution of Building Services Engineers, London, 1984.

[8] Watson, D. and Labs, K., Climatic Design: Energy-efficient Building Principles and Practices, McGraw-Hill, New York, 1983.

[9] Hui, S. C. M. and Cheung, K. P., Climatic data for building energy design in Hong Kong and Mainland China, In Proc. of the CIBSE National Conference 1997, 5-7 October 1997, London (paper for CIBSE Virtual Conference) 1997.

[10] Energy Design Resources by Architectural Energy Corporation, Boulder, CO., www.energydesignresources.com. 